\title{
Research Paper Opportunities and constraints in organic rice marketing - A study in Sirkazhi block of Nagapattinam district
}

\author{
M. PRIYANGA AND R. VENKATARAMAN
}

See end of the paper for authors' affiliations

Correspondence to :

\section{PRIYANGA}

Department of Agricultural Economics, Annamalai University, Annamalainagar, CHIDAMBARAM (T.N.) INDIA Email : priya93.agri@ gmail.com

Paper History :

Received : 12.08.2016;

Revised : 10.01.2017;

Accepted : 20.01.2017
Abstract : India is a large country with inherent geographic, ecological and cultural diversity and providing safe food to the nation is a challenging task. Production and marketing of organic food material is one of the way outs for providing safe food to the people. So, in order to analyse the opportunities and constraints in organic rice marketing, a study was conducted in Sirkazhi block of Nagapattinam district, taking a sample size of 60. Major findings emanated from the study which is based on the analysis on the constraints faced by the organic rice growers revealed that the prime constraint was the "risk of low yield" for the initial two years of transition from conventional to organic farming. The study indicated that 76 per cent of the farmers had awareness regarding certification and out of which only 64 per cent materialized the certification process. Reasons attributed for not growing certified organic rice showed that the "purpose for own family consumption" was the prime reason. Marketing channel study revealed that the farmers preferred to market organic rice through contract farming with CIKS. Awareness on consumption of organic rice showed that 60 per cent of the consumers having awareness on organic rice, out of which only 40 per cent of them were turned into organic rice consumers. Consumption pattern of organic rice revealed that out of the total consumers of organic products, 65 per cent of them were rice consumers. Factors determining consumers preference for organic rice exposed that "health" is the main attribute preferred by the consumers for shifting to organic rice consumption. Among the various options ensuring consumer credibility on organic rice purchase "buying organic rice from specific identified organic farmer" was considered as the best option, Marketing through small organic rice co-operative was the main suggestion given by the farmers to popularize organic rice consumption. Traders had awareness regarding organic rice but out of the total trader's only 20 per cent really marketing organic rice. The price factor appeared to be the key motivating factor for organic rice production, the healthy and safety factors were appeared to be the key motivating factors in the consumption or purchase of organic rice and unavailability of organic rice was found to be the major constraint in organic rice marketing.

KEY WordS : Opportunities, Constraints, Organic rice, Marketing

How To Cite This Paper : Priyanga, M. and Venkataraman, R. (2017). Opportunities and constraints in organic rice marketing - A study in Sirkazhi block of Nagapattinam district. Internat. Res. J. Agric. Eco. \& Stat., 8 (1) : 37-42, DOI : 10.15740/HAS/IRJAES/8.1/37-42. 